\section{Sediment-Hosted Stratiform Copper Deposits}

R.W. Boyle, A.C. Brown, C.W. Jefferson, E.C. Jowett, and R.V. Kirkham (eds.)

Geological Association of Canada, Publications, Department of Earth Sciences, Memorial University of Newfoundland, St. John's, Newfoundland A1B 3X5, Canada, 1989,710 p., Can $\$ 125$ plus $\$ 5$ postage and handling

The Geological Association of Canada has published as Special Paper 36 the proceedings of the symposium on sedimenthosted stratiform copper deposits held in May of 1986 at Carlton University, Ottawa, Canada. This is an important topic in the field of economic geology, not only because deposits of this type account for 25 percent of world copper production but also because discussion of their origin brings together many fields of geology from sedimentation and diagenesis to paleoclimatology and hydrology to tectonic history and basin analysis.

This report is divided into a general section and a section in which deposits and districts are described by region: Western Hemisphere, Africa, Australia, Europe, Middle East, and PRC. The general section begins with an excellent paper by R.V. Kirkham that reviews current knowledge about the grades and tonnages, world distribution, geologic environment, and origin of sediment-hosted copper deposits. A second paper by A.C. Brown discusses the perennial problem that geologists have in applying unique names to things and processes that are, by nature, gradational from one to the other. He concludes that the name chosen for the deposit type is satisfactory, though the term "stratiform" may, in some minds, exclude some deposits in continental red beds. Two papers describe the environment of formation: E.C. Jowett proposes continental rifting as the primary regional control for the deposits, and K.W. Glennie describes the importance of tropical deserts. Discussions of ore-forming processes include diagenetic alteration as the source for copper-bearing solutions by T.R. Walker; the mobility of copper, silver, cobalt, zinc, and lead in chloride solutions by A.W. Rose; and the effect of different sedimentary hosts and of brines of varying $\mathrm{pH}$ in the formation of contrasting base-metal deposits by H.P. Eugster. D.A. Sverjensky describes how carbonate, quartz sandstone, and red bed-anhydrite aquifers modify basinal brines and result in the formation of Mississippi Valley, sandstone lead, and stratiform copper deposits, respectively. L.D. Hoy and $\mathrm{H}$. Ohmoto examine the relationship between sulfur-isotope composition and sulfide and organic carbon contents in ore-bearing sediments. They conclude that, for many deposits, sulfide produced from the bacterial reduction of sulfate is modified by the addition of sulfide from hydrothermal or other abiogenic sources. J. Hoeve and D. Quirt compare and contrast stratiform copper deposits with unconformity-type and sandstone uranium deposits. The single Russian contribution to this section, by A.M. Lur'ye, is only two pages in length, which is unfortunate considering the importance of the Russian deposits.

The section on individual deposits, which contains interesting details and novel interpretations too numerous to list in this review, begins with North and South America. The lack of production from Canadian sediment-hosted copper deposits has not discouraged Canadian authors from taking a leading role in research on deposits of this type. Five papers on the Redstone deposit, Northwest Territories, and occurrences in Ontario, Alberta, and Nova Scotia, Canada, are balanced against an equal number from Montana, Michigan, Idaho, and New Mexico, USA. One paper describes deposits from the central Andes.

Six papers are presented on the ZaireZambia Copperbelt, as well as one on the Kalahari Copperbelt. Mount Gunson is the only Australian deposit described. Five papers discuss the Kupferschiefer deposits of Germany and Poland, and the remaining reports are about deposits in Iran, Israel, and PRC. No deposits are described from the Soviet Union.

The text and illustrations in this volume are very well edited, and a detailed subject index is included. Because of the breadth of scope of this volume, I recommend it to all geologists who are interested in the geochemistry of, or the mineral deposits in, sedimentary rocks.

Dennis P. Cox

Menlo Park, Califormia, USA

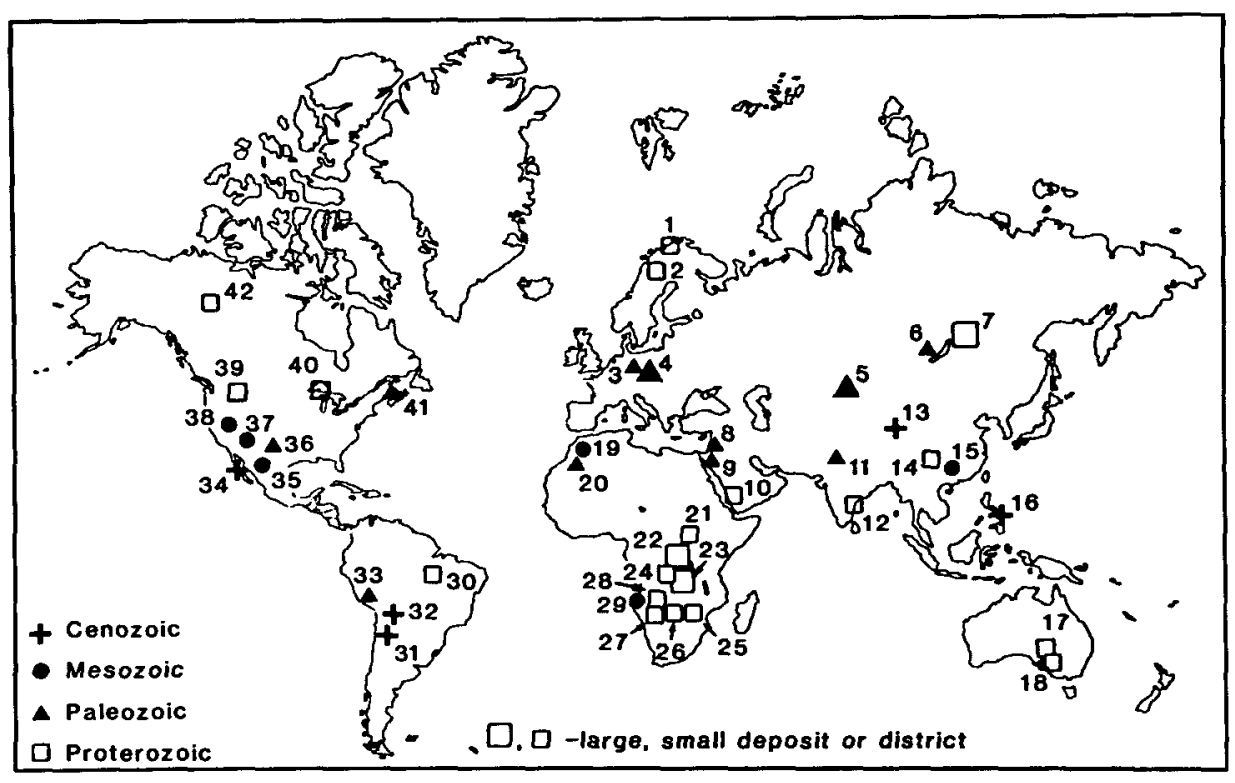




\section{Publications of the \\ INTERNATIONAL}

1. The Ordovician System in China Sheng Shen-Fu, 1980. US\$6.00. Stock Limited.

3. In search of the Paleogene Neogene boundary stratotype, Part 1-Potential boundary stratotype sections in Italy and Greece and a comparison with results from the deep sea. Available only from Gionale di Geologia, via Zamboni, 63-40128 Bologna, Italy, Not available from Episodes Office

\section{The Ordovician System in Aus-} tralia, New Zealand, and Antarctica B.D. Webby, et al, 1981. Correlation Chart and Explanatory Notes. 64 p., 1 table and 1 chart, US\$6.00.

7. An outline of the marine Triassic in China, Wang $Y^{\prime}-$ gang and others, 1981. 21 p, 2 tables and 1 map, US\$6.00.

8. The Ordovician System in Canada. C.R. Barnes, B.S. Norford, and David Skevington, Correlation Chart and Explanatory Notes. 27 p. 2 tables and 1 chart, US $\$ 6.00$

10. The Cambrian-Ordovician boundary-Sections, fossil distributions, and correlations, M, G. Bassett and W.T. Dean, (eds,), 1982, Published by National Museum of Wales, Geological Series 3, 227 p. Available from National Museum of Wales, Cathays Park, Cardiff, CF1 3NP, UK. $£ 17$ plus $£ 1,70$ for postage and packing, or from UUSS for US $\$ 29.00$ Not available from Episodes office.

11. The Ordovician System in southwestern Europe (France, Spain, and Portugal). W. Hamman, M. Robardet, and M. Romano, 1982. Correlation Chart and Explanatory Notes, 47 p, 1 figure and 1 chart, US\$7.50.

12. The Ordovician System in the United States. Reuben J Ross and others, 1982. Correlation Chart and
Explanatory Notes. 73 p. 4 figures, 1 table, and 3 charts, US\$10.00.

13. Southeast Asia-Tectonic framework, Earth resources, and regional geological programs. J A Katili and J.A. Reinemund, 1984,68 p. US\$11,00.

14. Stratigraphy quo vadis? E. Seibold and J.D. Meulenkamp (eds, , 1984. Published as AAPG Studies in Geology No. $16,70 \mathrm{p}$. Available from IUGS for US\$1 1.50. Stock Limited.

15. The Cambrian System in the Near and Middle East. R. Wolfart, 1983. Correlation Chart and Explanatory Notes, 70 p, 1 figure and 1 four-color chart, US $\$ 10.00$.

16. The Carboniferous of the World, Volume 1-China, Korea, Japan and S.E. Asia, C. Martinez Diaz, R.H. Wagner, C.F, Winkler Prins, and L.F Granados, 1983. Published by Instituto Geologico y Minero de Espana and Empresa Nacional Adaro de Investigaciones Mineras, S.A. Madrid, 245 p. A vailable from ENADIMSA Serrano 116, Madrid 6, Spain, or from IUGS for US $\$ 20.00$.

17. Petroleum resource assessment CD. Masters (ed), 1984. An introduction to the methods and procedures of assessing petroleum resources. $157 \mathrm{p}$, US $\$ 20.00$

18. Remote sensing for geological mapping. P. Teleki and C. Weber (eds.), 1984. Published as B.R.G.M. Document $82,313 \mathrm{p}$. (including 25 color plates) Available from B.R.G.M. B.P. 6009 , 45060 Orleans Cedex, France, 300FF plus $30 \mathrm{FF}$ postage, or from IUGS for US\$33.00. Not available from Episodes Office.

19. The Cambrian System in Australia, Antarctica, and New Zealand. J. Shergold, J, Jago, R. Cooper and J. Laurie, 1985. Correlation Charts and Explanatory Notes. 101 p., 8 four-color charts, US\$15.00
20. The Carboniferous of the World, Volume 2-Australia, Indian Subcontinent, South Africa, South America, and North Africa. C. Martinez Diaz, R.H. Wagner, C.F. Winkler and L.F. Granados (eds.) 1986. Published by Instituto Geologico y Minero de Espana and Empresa Nacional Adaro de Investigaciones Mineras, S.A, Madrid. 449 p. 37 plates. Available from ENADIMSA, Serrano 116, Madrid 6. Spain for US\$45 plus US\$5 postage and handling, or from IUGS for US\$50.00. For air mail add US $\$ 5$ to North American addresses, US $\$ 20$ elsewhere.

21. The Ordovician System in Kazakhstan and middle Asia. I.F. Nikitin, M.K. Appolonov, D.T Tzaj, V.G. Koroljov. A.I. Kim, M. V Erina N.M. Larin and A.N. Golikov, 1986. Correlation Charts and Explanatory Notes. 34 p., 3 figures and 2 charts, US\$7.50.

22. The Ordovician System in South America, F.G. Acenolaza and B. Baldis, 1987. Correlation Chart and Explanatory Notes, 68 p, 3 plates, US $\$ 1150$.

23. A global standard for the Silurian System. C.H. Holland and M.G.Bassett (eds.), 1989,325 p hardbound, Available from the National Museum of Wales, Cardiff, UK $(\$ 39.50$ plus postage of $£ 2.50$ UK or $£ .3 .50$ overseas, or from IUGS for US $\$ 72.00$ including postage.

24. The Cambrian System in eastern Asia. J.H. Shergold, A.R Palmer (eds.) 1988. Correlation Chart and Explanatory Notes 81 p., 4 charts, US $\$ 18.00$

25. The Cambrian System on the East European Platform. J.H. Shergold, A. Yu. Rozanov, A.R. Palmer (eds.), 1990. Correlation Chart and Explanatory Notes. 73 p, 1 chart, US $\$ 13.00$ 26. The Ordovician System in most of Russian Asia, 1988. Correlation Charts and Explanatory Notes, 115 p. 4 plates, US $\$ 18,00$.

Subscriptions to Episodes International Geoscience Magazine are US\$24,00 or $\$ 28.00$ Canadian. No discount is offered to Subscription Services. See the order form on the last page of this issue.

To order write to: Episodes P.O. Box 919 Herndon, VA 22070 or IUGS Secretariat Geological Survey-Norway

P.O. Box 3006, N-7001

Trondheim, Norway

Payments to Episodes for publications or subscriptions must be in US Dollars drawn on a US or Canadian bank, in Unesco coupons, or by VISA or MASTERCARD (Give account no, expiration date, and authorizing signature.) 